\title{
ADĂPOSTURILE SUBTERANE DE LA VARNIȚA - UN SIT NOU DE HIBERNARE A LILIECILOR
}

\author{
Caldari Vlad, Nistreanu Victoria, Dibolscaia Natalia, Larion Alina \\ Institutul de Zoologie, 2028 Chișinău, R. Moldova \\ vlad.caldari@mail.ru
}

https://doi.org/10.53937/9789975315975.04

Pe teritoriul R. Moldova exista 21 de specii de lilieci și majoritatea se întâlnesc în zona centrală și cea de nord a republicii deoarece au condiţii de existență favorabile, au adăposturi pentru hibernare, reprezentate de grote și mine părăsite. Mai mult de jumătate dintre speciile de lilieci din Moldova preferă diferite tipuri de adăposturi pentru reproducere și hibernare.

Carierele de piatră de la Varnița se află în zona centrală a R. Moldova pe malul drept a râului Nistru, coordonatele 46051'41"'N, 29028' $9^{\prime \prime}$ E. Minele se află în apropierea satului Varnița pe malul drept stâncos al râului Nistru și se întind pe o distanță de peste 300 m, iar adâncimea lor este de cca 150 m. Carierele sunt abandonate, au câteva intrări care nu sunt protejate, dintre care două sunt accesibile, cu diametrul de cca 1,5m înălțime și 2 m lățime, parțial astupate din cauza alunecărilor de teren, aici având acces publicul larg. Un plus este faptul că activităţile turistice și recreaţionale sunt puţin intense în timpul hibernării liliecilor. Tavanul are înălţimea cuprinsă între 2 și 3 m și constă din multiple crăpături de 5-10 cm, rămase în urma activităţilor de extragere.

Identificarea speciilor de lilieci s-a efectuat prin observații vizuale ale caracteristicilor morfologice, prin metoda capturării, prin înregistrări foto și video, prin identificarea pe baza ultrasunetelor cu ajutorul detectorului de ultrasunete. Una dintre metodele de observaţii indirecte este utilizarea detectorului de ultrasunete sau detectare acustică. Tehnica folosirii detectoarelor de sunete împreună cu caracteristicile zborului speciilor de lilieci într-un anumit habitat, precum și unele caracteristici de 
comportament duc la o identificare destul de exactă. Această metodă se utilizează preponderent în spații deschise precum și în păduri în timpul activității de zbor și vânătoare a liliecilor. În adăposturi subterane detectarea ultrasunetelor s-a utilizat în cazul când liliecii erau activi și zburau prin mine.

Capturările manuale cu ajutorul fileului s-au efectuat în interiorul și în zona de intrare în adăpost. Odată capturate, timpul identificării și măsurătorilor morfologice ale indivizilor a fost redus la minim, pentru a diminua nivelul deranjului animalelor. Pe parcursul studiului gradul de deranjare al speciilor prezente este cât mai redus prin iluminare minimă, numărare rapidă (sau numărare ulterioară pe fotografii), un nivel minim de zgomot, intervenții minime în timpul studiilor morfologice și taxonomice. Pentru cercetările de monitorizare a liliecilor a fost utilizat următorul echipament: îmbrăcăminte specială, lanterne, camere foto digitale, detector de ultrasunete D-230 (Pettersson Elektronik, Suedia), șubler, cântar electronic, aparat pentru măsurarea temperaturii și umidității (termometru/ higrometru), fileu pentru capturarea animalelor, inele pentru inelat.

Informațiile colectate au fost notate în registre de teren, conţinând datele climatice, caracteristicele geografice și ecologice ale adăpostului, eventuale modificări în starea naturală a adăpostului și alte. Identificarea speciilor prezente în adăpost s-a bazat în primul rând pe caractere morfologice ușor de recunoscut (de ex. învelirea în aripi la Rhinolophidae, postura tipică a liliecilor cu aripi lungi, colorația blanei, dimensiunile corporale etc.).

Cercetările au avut loc în ianuarie 2016 și februarie 2018. În ambele perioade studiu timpul a fost destul de cald, cu temperatura de 5,2- 6,50 $\mathrm{C}$ și $7-7,50^{\circ} \mathrm{C}$, respectiv.

Prima intrare, la $5 \mathrm{~m}$ umiditatea era de $40 \%$, temperatura de $5,3^{\circ} \mathrm{C}$, îndată după intrare se începe coridorul care apoi se ramifică în mai multe treceri subterane și încăperi. Intrarea a 2, la 5 m umiditatea era de 50\%, temperatura $8,4^{\circ} \mathrm{C}$, după intrare coridorul se ramifică în mai multe direc- 
ții. Au fost parcurși cca $800 \mathrm{~m}$ de treceri subterane și au fost semnalate 5 specii în ianuarie 2016: liliacul urecheat cenușiu (Plecotus austriacus) - 1 individ la câțiva zeci de metri de la intrare, 2 indivizi de liliac cu mustăți (Myotis mystacinus), unul din care a fost cântărit și avea $7 \mathrm{~g}$, liliacul mic cu potcoavă (Rhinolophus hipposideros) - 18 indivizi care dormeau solitar, un individ de liliac de iaz (Myotis dasycneme) și 35 indivizi de liliac de apă (M. daubentonii), care au fost cei mai abundenți. În total au fost semnalați 57 indivizi din 5 specii, iar proporția lor a fost următoarea: $R h$. hipposideros - 31,58\%, M. daubentonii - 61,41\%, M. dasycneme $-1,75 \%$, M. mystacinus - 3,51\% și P. austriacus - 1,75\%.

În februarie anul curent au fost semnalate doar 2 specii: liliacul mic cu potcoavă (Rh. hipposideros) și liliacul de apă (M. daubentonii). În prima mină au fost observați 36 indivizi de liliac de apă și 19 indivizi de liliac mic cu potcoavă. În a doua mină s-au observat 11 indivizi de liliac de apă și 13 indivizi de liliac mic cu potcoavă. În total au fost semnalați 79 indivizi din 2 specii: Rh. hipposideros cu 40,51\% și M. daubentonii cu 59,49\%.

Carierele de la Varnița reprezintă un nou sit de cercetare a procesului de hibernare a comunităților de chiroptere și este de o importanță majoră pentru conservarea speciilor de lilieci, deoarece toate speciile înregistrate pe parcursul studiilor sunt rare, incluse în Cartea Roșie a Republicii Moldova.

Studiile au fost efectuate în cadrul proiectului fundamental 15.187.0211F realizat la Institutul de Zoologie. 